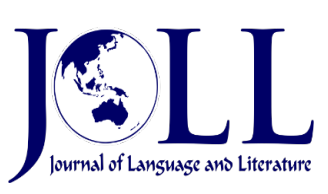

Vol. 21 No. 1, April 2021, pp. 58 - 67

DOI: 10.24071/joll.v21i1.2783

Available at https://e-journal.usd.ac.id/index.php/JOLL/index

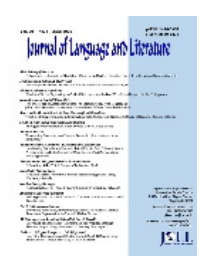

This work is licensed under a Creative Commons Attribution-ShareAlike 4.0 International License.

\title{
Positioning the Portrayal of White Protagonists in O.A Bushnell's the Return of Lono and Ka'a'awa
}

\author{
Kristiawan Indriyanto, Ida Rochani Adi \& Muh. Arif Rokhman \\ kristiawan.i@mail.ugm.ac.id; idaadi@ugm.ac.id; arokhman@ugm.ac.id \\ Doctoral Program of American Studies, Universitas Gadjah Mada, INDONESIA
}

\begin{abstract}
This paper explores the role of literature in the post-truth age through reading on O.A Bushnell's the Return of Lono and Ka'a'awa. A Hawai'ian novelist, Bushnell contextualizes the earliest interactions between the native Hawai'ian (Kanaka Maoli) and the white settlers which began with the arrival of Captain Cook's expedition in 1778. Through his fictions, Bushnell underlines positive portrayal of the white characters to provide a counter-discourse to the generally accepted history of Hawai'ian colonialism. Through first person point of view, white characters become the central figure in both of Bushnell's fictions. Through reading on O.A Bushnell's narration, this paper aims to elaborate how the Hawai'ian natives also become a willing partner in western colonialism which highlights their colonial complicity. The concept of colonial complicity is employed to highlight the participation of the natives in promoting Western way of thinking. The analysis argues that although Bushnell contextualizes the complicity of the Hawai'ians in promoting Western discourse, resistance also occurs through creation of a hybrid culture. This paper concludes that in the post truth era, literature should always strive to uncover the truth based on subjective interpretation instead of abiding of a universal truth.
\end{abstract}

Article information

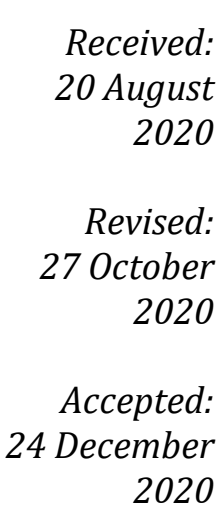

2020

Keywords: Hawai'ian literature, post-truth, colonial complicity

\section{Introduction}

In the closing of the year 2016, the world is moving toward the post truth era. Although several monumental events in 2016 such as Brexit, the election of Donald Trump into the seat of U.S presidency and the declaration of Turkish President -Erdogan concerning a state of emergency in Turkey, it is not to say that pre-2016, the existence of post truth is in limbo. The emergence of post truth era has been foreshadowed by several historical events. Media news covering the Gulf Wars, false accusation that Iraq's leader, Saddam Hussein is in possession of Weapon of Mass Destructions (WMD) and the subsequent War of Terrors are several examples of disinformation and hoaxes which infers that empirical existence of post truth has long been in existence (Mejia et al., 2018, p. 110). Yet, it should be underlined that the events post2016 dramatically shapes the current situation 
of post truth era. The aftermath of US presidential election, especially the spread of information in the era of social media plays a pivotal role in creating a post truth world. Fake news that thrived by conforming readers' gut feeling, such as hyperbolically inflated number of immigrant -mainly Muslim refugees- is widely accepted by Trump's supporters, without bothering of checking the fact (Willsey, 2018, p. 500)

In this post truth era, questions arise regarding how to position disciplines in humanities field, especially literature in the rapidly changing world. On her article, Fiction in the Post-Truth era (2017), Worthington argues that post truth's appeals to emotion and personal belief instead of objective facts causes the rising surge of popularity in memoir and autofiction. Her reasoning is that, after realizing that the notion that 'the Truth' is no longer relevant to us (the readers), they become more and more invested in knowing a particular version of the truth (2017, p. 476). Compared to other genres of literature, memoirs reflect their writers' very specific view of the truth or can be stated as subjective truth.

Another opinion is proposed by Di Battista and Hubener in the Environmental Humanities in a Post-Truth World (2017). Focusing especially on the prevalence of climate change denials in Trumpian government, they reiterates the key roles of artists, writers, activists, scholars and critics to "uncover truth, to hold reality up to the light so that it cannot be denied....reaching wider audiences and engaging in truly public realitybased discourse should be a top priority" (2017, p. 2). In an era that blurred the line between fiction and reality, literature and critical analysis remain as important as ever. Literature, both writers and critics should continue to offer interpretation in seeking for truth through literary analysis.

Contextualizing how literature is viewed within the context of the post- truth era, some commentaries concerning the term itself should be addressed. According to Oxford Dictionary, post-truth is relating to or denoting circumstances in which objective facts are less influential in shaping public opinion than appeals to emotion and personal belief (in Battista \& Huebener, 2017, p. 34). This word experiences a surge in popularity during the outcome of the Brexit referendum in June 2016 and Donald Trump's election as U.S President at November 2016. The popularity of the term post truth as a result of the divisive public opinion of the aforementioned events causes this word to be chosen as Oxford Dictionary Word of the Year in 2016. In the context of these events, Musolff summarizes how "the notion that truth is under severe attack has become a commonplace that is continuously reinforced by coverage of 'fake news', 'alternative facts', 'truth markets' and competing publics, especially in internetbased media" (2019, p. 355). In this post truth era, the claim that opposing sides spread fake news and hoaxes is enough to make the audience lose interest in paying attention to them and unwilling to align themselves into the speaker's intention.

On his book, the Work of Literature in an Age of Post-Truth (2018), Schaberg extrapolates the position of literature in the current post truth era. Schaberg argues that literature by definition is an avenue for post truth opinion,

to be wary of truth with a capital ' $T$ ', definite or absolute claims...ahistorical and universal. Careful studies of rhetoric and context often reveals claim of Truth to be riddled with contradiction (2018, p. 1).

Post-2016, the notion of post truth suddenly swerves into the negative, in which post truth is associated with hoaxes, lying and half-truth. A literature work by nature is fictional, or a verisimilitude of the reality itself, even an autobiography, as author $\neq$ narrator $\neq$ character (Genette et al., 1990, p. 350) . Based on this definition, it cannot be stated that literature offers false perceptions, disinformation or hoaxes, as literature rejects the claims of a universal truth. The universal "truths" characteristics of literary works are often unverifiable: they are too general, they have an essential value component, they are grounded in a highly personal outlook, and so forth (Lamarque, 2010, p. 380). Stating his argument on literature within the post truth world, Schaberg asserts the potential of 
literature to connect people across culture, but should also remain true to the multiinterpretative trait of literary works.

In an era of rapid compartmentalization, where people's beliefs and political stance are all too frequently cordoned off from one another...the work of literature can connect people, a novel can conjure a whole world. But the work of literature might also present ways to think across different things, to see amalgram, disjunctions, and the murky areas of overlap and co-shaping (2018, p. 144).

This paper aim to contribute toward locating literature in the post truth era through postcolonial reading on the Return of Lono and $K a a^{\prime} a w a$, two novels written by O.A Bushnell, a Hawai'ian novelist. As a nation who is illegally annexed by the U.S in the 1899, a culmination of years of colonialism and economic domination, resistance toward U.S occupation is articulated by the Native Hawai'ians ethnic group (Kanaka Maoli). One of the most vocal critics of the ongoing American domination is Haunani-Kay Trask, a prolific native writer, activist, and lecturer in the University of Hawai'i in Honolulu. Her strong Anti-American stances is underlined in several of her articles and speeches. Several of which are, "the Americans, my people, are our enemies" (Kay-Trask, 1993, p. 75) and also "we need to think very, very clearly about who the enemy is. The enemy is United States of America and everyone who supports it" (in Scanlan, 2017).

Moreover, Kay-Trask's disdain toward America also manifests in her rejection of any Hawai'ian literature which is not written by the islanders itself. This view is expressed through her statement that "Hawai'ian literature is that which is composed by Hawai'ians.... residence in Hawai'i does not make one Hawai'ian." (1999, p. 168) This narrow-minded genealogy of Hawai'ian literature is rejected by other scholars, mainly Ho'omanawanui who instead proposes the anthologized Hawai'ian literature based on both geographical and thematic elements (2015, p. 227). Based on Ho'omanawanui's conception of Hawai'ian literature, O.A Bushnell, a Westerner is included as a figure of
Hawai'ian literary scene, a convention which is scorned through Kay-Trask refusal to acknowledge non-Hawai'ian writers. Bushnell's fictions reimagine the early period of Hawai'ian colonialism and explores that the Hawai'ian natives, contrary to what Kay-Trask asserts is also a complicit party during the colonial period.

Several prior analyses on Hawai'ian literature, especially novels written by 0 . A Bushnell have been conducted. On his article, Indriyanto (2020) foregrounds the articulation of aloha aina epistemology in $K a^{\prime} a^{\prime} a w a$ that considers the surrounding landscape as part of Hawai'ian ohana/family as a possible avenue to counter the anthropocentrism of Western society. He explores how this paradigm lies in stark contrast with the Western anthropocentric view that places human beings as agents of imperialism, and nature as mere commodity is subjected to exploitation, plunder, and pillage $(2020$, p. 4). It can be seen how previous analysis of Ka'a'awa emphasizes more on the environmental ethics that regulate human and non-human relationship instead of analyzing the representation of white/haole characters.

Another extrapolation of Bushnell's literature comes from Liangphinith's finding (2015). Her argumentation focuses on positioning Bushnell's fictional works as an example of 'local' literature due to Bushnell, although a white Caucasian was born and raised in Kaka'ako in Honolulu (2015, p. 22). Different with these prior analysis on O.A Bushnell's novels, this paper exemplifies upon the representation of white protagonists to challenge the claim that Hawai'ian literature should only be written by Native Hawai'ians.

Moving back into an analysis of O.A Bushnell's the Return of Lono and Ka'a'awa, it is important to underline that the colonialism in Hawai'i as reflected in these novels is foregrounded in a different angle, from the perspective of the white settlers. Bushnell contextualizes how the encroachment of Western powers and their eventual colonization on this archipelago is also supported in no small part from the willing participation of the natives or their complicity. Colonialism occurs due to the complicity of the 
colonized in accepting the process of colonialism and become a willing partner. Ulla Vuorela defines it as the participation of the colonized in the hegemonic discourses, involvement in the promoting of universal thinking, and practices of domination" (2009, p. 19). Through the powerful and authoritative Western civilizing process, the colonized are lured to take part in its process $(2009$, p. 1) Derived from Vuorela's concept of colonial complicity, the analysis explores how the Hawai'ians islanders themselves are also a complicit party in their resulting state of being dominated by the Whites.

The complicity of the colonized is based on inequal power relations that designates the inferiority of the non-Western civilization. As theorized by Ashcroft et al, (2007, p. 32) the non-Western people are delegated as the Other, devout of culture, religion and language before the entrance of the West as civilizing powers. This paradigm that denigrates the non-West agency results in inferiority complex which eventually leads into the adoption of Western way of living. Fanon theorizes the existence of 'mental colonialism' in which the colonized party felt inferior to their own culture due to Western colonialism (1963, p. 5). This problematic struggle will be further expounded in the analysis.

\section{Methodology}

This study is qualitative research that employs two novels written by 0 . A Bushnell, a Hawai'ian-American writer, the Return of Lono (1971) and Ka'a'awa (1972). Qualitative research aims to explore and understand individuals or groups ascribe to a social or human problem (Cresswell, 1998, p. 77). The analysis is conducted by underlying several quotations of the texts and arguing how the representation of white characters is viewed in a positive light, to counter the demonization of whites/haole by several Hawai'ian scholars. Besides positioning the literature as primary data, the present study also provides secondary data from journals, articles, and essays to better contextualize the historical situation in Hawai'i.

\section{Results and Discussion}

\section{Reinterpretation of Captain Cook and Colonial Complicity in The Return of Lono}

O.A Bushnell's the Return of Lono and Ka'a'awa contextualizes the condition in Hawai'i during the early period of Western colonialism by foregrounding the role of the white protagonists. In the Return of Lono, Bushnell refigures the portrayal of Captain Cook, the man who leads the expedition to discover the Hawai'ian archipelago to place him in a more positive portrayal. In his foreword, Bushnell acknowledges that "one of the greatest ironies in Hawaii's history lies in the fact that the greatest man to visit her shores is today the least known and the most despised" (1971, p. 55). While the ones who irrevocable shape the political and religious situation in Hawai'i is the American Protestant missionaries in the 1820's, Bushnell argues that the Hawaiians places the blame of their current plight on Captain Cook instead. Bushnell's portrayal of Captain Cook refigures his depiction in a positive pedestal. Instead of a figuration of Western explorer who is hellbent of claiming the riches of the undiscovered islands to British crown, Cook is depicted as sympathetic to the diseases his sailor unknowingly brought to the isles, respectful to the local customs and the kahuna (shamans) as the Hawai'ian religious authority.

Extrapolating on the circumstances dealing with Captain Cook's discovery of the Hawai'ian isle, mainly on the bay of Kealakekua, island of Hawai'i is intertwined with the joyful celebratory -held by the natives - to commemorate his arrival. This event becomes a point of contention in modern Hawai'i, especially the reaction of the natives at that time toward the arrival of Cook's expedition. Reading on several elementary school textbooks such as Hawaii the Aloha State (1982), Kaomea questions how the records of Cook's voyage describes the natives as 'very happy that we (the expedition) had come." Knowing that Captain Cook's discovery of Hawai'ian archipelago ultimately brought disease and destruction, she finds it strange 
that the Hawai'ian islanders initially welcome Cook's expedition with bountiful hospitality. (2000, p. 232). In Bushnell's interpretation, the circumstances concerning Captain Cook's arrival on the Kealakekua bay is entirely coincidental. Besides arriving at the festive period Makahiki, Cook's voyage coincides with the ancient Hawai'ian prophecy that the exiled God of fertility, Lono will eventually returns on floating islands.

As aforementioned, Bushnell's the Return of Lono provides a counter discourse towards the denouncement of Captain Cook in modern Hawai'i. Answering Kaomea's claim that the whites brought untold diseases and destruction to the Hawai'ians people, Bushnell narrates how Cook is aware to the venereal plagues his sailor brought to this isolated isle, and is deeply troubled with this fact. His previous expedition on the island of Kau'i leads his unsupervised seaman to share the bed with local women, and unwittingly unleashes venereal diseases among the natives.

"Aye," the Captain answered him bitterly. "The chief est scourge of Hell has been released among the natives of these islands: it appears that the venereal disease, that gift of civilization, was left by our crews at Kauai, when we visited there a year ago." The Captain did not gainsay him. "You see, gentlemen, how good intention is circumvented by lusting men." The scorn in his voice showed how disappointed he was in his men. (Bushnell, 1971, p. 40)

Unwilling to commit the same mistake, Cook orders that no members of his expedition to have sexual intercourse with the women in Hawai'i isle. "Let us try to give them here as long a freedom from this malady as we can," he cried (1971, p. 42). Disobedience is considered a capital offence and will be punished by twenty lashes at the mast. Good intentioned man as he was, it is beyond his control that years after his expedition, after the Hawai'ian archipelago is firmly anchored in a global networks, sailors, whalers, and pirates with no such sexual restrains cause epidemic of syphilis and measles that devastated the indigenous islanders (Haley, 2016; Inglis, 2013; Kuykendall, 1938).
Bushnell's portrayal of Captain James Cooks exemplifies his respect towards the indigenous islanders' culture and customs, and although he is deified as the second coming of Lono, he does not misuse his capabilities. Admiring the physical appearances, health and cleanliness of the Hawai'ians, Cook considers the islanders as the representation of 'noble savage' and intends to endeavor, by all proper means, to cultivate a friendship with them (1971, p. 33). He outspokenly admires "the widespread Polynesian tongue...how the natives outdo the English in seamanship, with nothing more than canoes for their journeying" (1971, p. 55). No one among the natives is most revered than the High Chief of Kona and Kau, Kalaniopuu. In the lead, standing upon the platform joining the two great hulls of the double canoe, were thirty men of rank, some of whom were dressed in the most magnificent feathered cloaks we had ever seen (1971, p. 50).

As aforementioned, although Cook is deified by the natives, and his status allows him to exhort the natives without repercussion in a strict kapu system, he does not abuse his prerogatives. He orders his sailor to be restrained in taking things from the countryside, such as woods from the mountain to repair the ship, in preparation for further voyage (1971, p. 123). This is in total contrast with another example from Herman Cortez, for example, how his status as God Quetzalcoatl conducts him to blackmail Emperor Montezuma II to remove all the riches from Tenochtitlan for the benefit of Spanish invaders (Martinez, 1996, p. 215).

The submissiveness and obedience of the local islanders toward Cook's arrival, and eventually the Whites on a mass-scale can be interpreted to highlight their colonial complicity, how they willingly assists the colonialism of the Western power. Kaomea believes that the obeisance of the islanders is caused by their inferiority of the foreigners' military forces, mainly their firearms (2010, p. $20)$. Although this is one factor, this paper asserts that the Hawai'ian's own system of law and regulation, the kapu system plays a more pivotal role. Kapu is a system of taboo in which the people are segregated based on their social classes, chiefs (alli) and the priests (kahuna) 
are the highest in the hierarchy. "The common people were kept under control by the regimen of kapu, a complex list of foods, lands, and practices that were forbidden to defined classes of people" (Haley, 2016, p. 29). This draconian law which is punishable by death stark contrasts with the seemingly peaceful idyllic paradise in the Pacific Ocean.

The authority of the chiefs was sacrosanct, founded on their descent from the gods; and their policy and minister of state were the dreaded priests, the kahunas. Beneath these lordly ones, at the pinnacle of their pyramid of rank, were the lesser chiefs and the lesser kahuna, and supporting them, in the misery of the mass, were the commoner. (Bushnell, 1971, p. 115)

The kapu system persists for over a thousand years, since the ancestors of the Hawai'ians people migrate from Tahiti to the north, yet the arrival of the Whites irrevocably molds the power dynamic of Hawai'ian society. The Chiefs and priests claim descent of the gods and no one stands above them in the hierarchy except the gods themselves. The arrival of Captain Cook's expedition, whom he is deified as Lono returned immediately places Cook and his fellow seaman in the pinnacle of Hawai'ian society. Even in the ceremony, the revered Chief Kalaniopuu immediately prostrates in front of the voyagers, "settling into it slowly and stiffly, as if it were a position new to him, never before faced with superior rank" (1971, p. 64). While Cook was unable to witness the vast changes of Hawai'ian society due to his untimely death, the collapse of kapu system, and the subsequent introduction of Western way of living occurs no less than half a century later, a situation represented in Bushnell's other novel, Ka'a'awa. The inferiority complex of the Hawai'ians, due to the seemingly superior Western culture, tradition and custom plays a pivotal role in abandoning their ancestral tradition.

\section{Colonial Complicity, Hybridity and Resistance in Ka'a'awa}

Ka'a'awa : A Novel about Hawaii in the 1850 's -shortened to Ka'a'awa - chronicles the rapid changes in Hawai'ian society due to Western colonialism. The old kapu system is abolished, the kahuna who still held true to the old ways are slowly being phased out, the missionaries become the king's advisors and ministers and land across the isles is parceled out for the settler's plantation and growing industry. The rapidly changing society becomes the concern of Bushnell's narration which is revealed through two main characters. The two protagonists of this narration represent the opposite spectrum in this turmoil period, Hiram Nihoa, advisor of the Fourth Kamehameha, Alexander Liholiho and Saul Bristol, a foreigner who although at first treat the natives with scorn and disdain, eventually immerse himself in the local tradition.

First half of the story deals with Nihoa's travels all around O'ahu island to comprehend the vast changes in his home island, some two decades after the kapu system was abolished. The formidable Queen regnant, Ka'ahumanu, wife of the Kamehameha the Conqueror -in no small part by her husband's interaction with the whites - enact the prohibition of the thousand-year-old kapu system. For years, she had observed foreigners break kapus repeatedly, and no volcanos erupted, the officers and traders who called at the island had no kapus, and they lived healthier and more abundantly than her people (Haley, 2016 , p. 46). Seaton acknowledges that the abolishment of the kapu system is the only known time in the history of the world when a people threw over a long-establishment religious system with nothing to replace it (1974). The void of religious authority is soon filled by American Calvinist missionaries.

In Bushnell's Ka'a'awa, two decades has passed since the beginning of proselytizing of the Kingdom of Hawai'i in the mid 1830's. The introduction of Christianity through Western missionaries is legitimized under the stigma of paganism towards Hawai'ian polytheistic belief. As explored by Indriyanto (2020, p. 60), western discourse positions Hawai'ians epistemology that emphasizes the sanctity of nature as heathenish, contrary to the Christian belief in which nature exists to serve humanity. Traditional Hawai'ians dances such as hula is considered as a sinful practice that promote sexuality. In Ka'a'awa, Bushnell depicts an event in which the Hawai'ians characters, 
influenced by Western perception of hula refuse to held a hula performance

Old people have forgotten the old ways. Because they, in turn, were influenced by the American missionaries, who hate and decry our heathen dances. By this time, they were in a frenzy of lasciviousness, revealing the hula-hula in its very worst excessesand at its sensual best. (Bushnell, 1972, p. 209)

The complicity of the Hawai'ians people in embracing Western traditions and abandoning their belief results in resistance. Bushnell narrates how the Hawai'ians, such as his protagonist, Hiram Nihoa while openly proclaims themselves to be Christian and attend Sunday prayers, keep on preserving the old ways by worshipping the ancestral Hawai'ian deities. During his journey all across the island of O'ahu, Nihoa prays "first to Jehovah, then Kane, Ku, Lono, and Kanaloa, the four great gods, and the forty lesser gods" (Bushnell, 1972, p. 17).

Through Nihoa's perspective, Bushnell intends to create an acculturation of cultures between the Western Lord and Hawai'ian deities, or in other word hybrid culture. Nihoa's assertion, “"'after all, did they (Hawai'ians deities) not live in these blessed isles long before Bingham and Jehovah come?" (Bushnell, 1972, p. 67) illustrates the Hawai'ians' hybridity in which they preserve their custom under dominant Western discourse. Some powerful high chiefs even be deviant enough to continue the worship of the pagan tradition such as the Kanemilohai.

They nevergo to church, these ancient ones, less because of their age, I suspect, than because of their devotion to the pagan gods. They give me no proof, of course, that they cling to the ancient religion, but anyone who is not blind can conclude as much from the care with which they maintain the pagan temple that adjoins the household. Unlike other temples I have seen, invaded by weeds and shrubs, ragged around their edges where the loose rocks have been knocked down by zealot Christians or by careless children, this one is in perfect order (Bushnell, 1972, p. 219).
Another example of the Hawai'ians' resistance toward Western colonialism is asserted through Nihoa's refusal to use English names in referring to local places. As theorized by Adams (2003, p. 24), the act of naming and classification of both people in places in English language is intended as an apparatus of control. Furthermore, different with Hawai'ians place names in which " a name of a place is special, unique, and sacred" (2005, p. 25), renaming in English is arbitrary, in which there is no correlation between the names employed and the place. Nihoa's refusal to acknowledge the renaming of Hawai'ian place in English highlights another nuance of resistance in preserving the local tradition, legend, and myth behind place names.

The back of Punchbowl, where it meets the hillside which nowadays is called $\mathrm{Ka}$ Papakolea, which is to say Plover Flat. "Everything is being named anew," When first I came to live in Honolulu, this place called Ka Papakolea had another name: Kewalo it was called then. That hill called Punchbowl-there is another of those ugly haole names (Bushnell, 1972, p. 72).

Second half of $K a^{\prime} a^{\prime} a w a$ is recounted from the perspective of a white man (haole), Saul Bristol. Originally intended to escape America into Asia, he is stranded by a shipwreck and is found by Alex Liholiho, the future Kamehameha IV. While at first he is detached from the natives around his farm in Ka'a'awa, an outbreak of measles and influenza that devastated the indigenous population encourages him to devote his living for the advancement of the community. It is important to underline that it is a white man, a foreigner who express his plight toward the miserable state of the islanders instead of their local chiefs and other authorities.

From that vantage, where once chiefs and priests must have gazed out upon fertile fields and hundreds of happy people, today I saw only desolation. The people are gone, dead and vanished into the earth, and among the smothering weeds only the stone platforms upon which once their houses rose, only a few sagging, rotting grass huts, remain to show that this was a 
thriving community (Bushnell, 1972, p. 220).

Similar with his portrayal of Captain Cook in the Return of Lono, the White character in $K a^{\prime} a^{\prime} a w a$ is viewed sympathetically. While at first Bristol abides to the colonialist discourse that considers the inhabitant of Ka'a'awa valley as "little more than an animal, whom I condemned for their brutishness" (Bushnell, 1972, p. 318), he later becomes sympathetic to the plight of the islanders. The suicide of high chief Kanemilohai and his entire family by burning causes Bristol to be considered as the chief of Ka'a'awa by the local villagers. In the rapidly changing world due to their arrival of Western missionaries and traders, the natives are honored by how Bristol teaches new ways of cultivating the land, western agriculture and educating the natives and their offspring's in reading and writing. "I was a schoolmaster in America. I shall teach you not only the reading and the writing. I shall teach you all I know about the great world beyond the sea" (p. 283284).

Both protagonists express their caution on the present stance of Hawai'ian society. The erasure of the kapu system has caused the old ways to be forgotten, and with diseases that strikes the isles, the majority of the high chiefs are now deceased, or reside in Honolulu without knowing what happened in the outskirt area. "The old ways are being forgotten, if they are not already abandoned, and nothing new has taken their place. Now the people live in filth as well as in want." (p.259) Bushnell stresses how the Hawai'ians are experiencing inferiority complex ever since the arrival of Captain Cook's expedition. Feeling that the Whites are superior in every way conceivable to them, religion, technology, no restriction of the kapu system, the Hawai'ians are made to feel ignorant and useless, as is seen in this passage:

I think that we are a dying race because now we live in fear, not in harmony. Because we do not know what to do or what to believe. Because we have lost our respect for ourselves. This is the worst thing the foreigners have done to us: in so many ways they have made us to feel that we are ignorant and useless. In so many ways, they have taken away our respect for ourselves (1972, p. 369).

This inferiority complex, to quote Fanon's assertion is one reason for the colonial complicity of the Hawai'ian islanders. Under the binarism that delegate Western tradition and custom as heathenish, barbaric and backwards, the allure of Western civilization rapidly transforms the Hawai'ians' way of thinking, in line with the Western standard. The refusal to held a hula performance under the belief that this dance promotes sexuality is one example of Hawai'ian internalization of what the Westerners think about themselves. Through his narration, Bushnell provides several examples of resistances toward dominant Western discourse through Nihoa's acculturation of ancestral Hawai'ian deities and Christianity.

Based on the analysis of colonial complicity and resistance this paper asserts that Bushnell's narration provides a counterdiscourse toward the strong-anti colonialist tone of the Hawai'ian nationalist such as Haunani Kay-Trask. His portrayal of white characters depicts them positively as someone who is concerned with the plight faced by the islanders. Although Bushnell explores the colonial complicity of the islanders in promoting Western way of thinking, this paradigm also results in resistance in the form of creating a hybrid culture. This phenomenon highlights the negotiation between two cultures, Hawai'ian and the West, which in Schaberg's idea is riddled with "amalgram, disjunctions, and the murky areas of overlap and co-shaping" (2018, p. 144).

\section{Conclusion}

Based on the analysis of Bushnell's fictions, this paper argues that in the post truth era, literature should always strives to uncover the truth. It is not to say that universal or general truth should be taken for granted, but instead offering a multi interpretation of literature, as what literary critics has been done up to this point should be continued. In line with Schaberg's arguments, literature offers more than one way of percieving truth, to see amalgram and area of overlapping which differs from one scholar to another. The 
reading of Bushnell's the Return of Lono and $K a^{\prime} a^{\prime} a w a$ exemplifies how the Hawai'ian islanders themselves are also complicit in the spread of colonial discourse. Their abolishment of the kapu system indicates their inferiority complex, how Westerners that are unbound by the restrictive systems prove their superiority compared to the indigenous people. They lose their self-esteem, their respect, and their dignity, adopting the Western ways and abandoning their ancestral beliefs. Yet it should be noted that their complicity also results in resistance through the creation of a hybrid culture.

\section{Acknowledgement}

This paper is part of the ongoing dissertation written by the author entitled Lingkungan dalam Karya Sastra Diaspora: Kajian Ekokritik Poskolonial terhadap Sastra Amerika-Hawai'i. The argumentation mainly covers the third chapter of the dissertation. This writer expresses his gratitude toward the insight given by the supervisors; Prof. Dr. Ida Rochani Adi, S.U and Drs. Moh Arif Rokhman., P.hD during the writing process.

\section{References}

Adams, W. M. (2003). Nature and the colonial mind. In W. M. (William M. Adams \& M. Mulligan (Eds.), Decolonizing Nature: Strategies for Conservation in a Postcolonial Era (pp. 16-50). Earthscan Publications. https://doi.org/10.4324/978184977092 7-8

Ashcroft, B., Griffiths, G., \& Tiffin, H. (2007). Post-Colonial Studies: The Key Concepts, Second Edition (Second Edi). Oxford: Routledge.

Battista, A. M. Di, \& Huebener, P. (2017). The Environmental Humanities in a PostTruth World. The Goose, 15(2), 1-6.

Bushnell, O. . (1971). the Return of Lono : A Novel of Captain Cook's Last Voyage.
University of Hawai'i Press.

Bushnell, O. A. (1972). Ka'a'awa : A Novel about Hawai'i in the 1850s. Honolulu: University of Hawai'i Press.

Cosma-Gonsalves, M. (2005). East Hui Resource Management Newsletter.

Creswell, J. W., \& Poth, C. N. (1998). Qualitative Design and Research Design : Choosing Among Five Approaches. New York: SAGE Publications, Inc.

Fanon, F. (1963). The Wretched of the Earth. New York: Grove Press.

Genette, G., Ben-Ari, \& McHale, B. (1990). Fictional Narrative, Factual Narrative. Poetics Today, 11(4), 755-774.

Haley, J. L. (2016). Captive Paradise- A History of Hawaii. New York: St Martin's Press.

Ho'omanawanui, K. (2015). Hawaiian Literature. In Emmanuel S Nelson (Ed.), Ethnic American Literature : An Encyclopedia for Students (pp. 227-232). Connecticut: Greenwood.

Indriyanto, K. (2020). Aloha Aina: Native Hawai'ians' environmental perspective in O.A Bushnell's Ka'a'awa. Rupkatha Journal on Interdisciplinary Studies in Humanities, 12(1), 1-12. https://doi.org/10.21659/rupkatha.v12n 1.04

Indriyanto, Kristiawan. (2020). Manifestation of colonial discourse and anthropocentric outlook in james michener's Hawai'i. Okara : Jurnal Bahasa Dan Sastra, 14(1), 51-66. https://doi.org/10.19105/ojbs.v14i1.318 5

Inglis, K. A. (2013). Ma'i Lepera : A History of Leprosy. Honolulu: University of Hawai'i Press.

Kaomea, J. (2000). A Curriculum of Aloha? Colonialism and Tourism in Hawai'i's Elementary Textbooks. Source: Curriculum Inquiry, 30(3), 319-344. http://www.jstor.org/stable/3202105

Kay-Trask, H. (1993). From a Native 
Daughter : Colonialism and Sovereignty in Hawai'i (Revised Ed). Honolulu: University of Hawai'i Press.

Kuykendall, R. S. (1938). The Hawaiian kingdom, vol. 1, 1778-1854, foundation and transformation. Honolulu: University of Hawai'i Press.

Lamarque, P. (2010). Literature and Truth. In G. L. Hagberg \& W. Jost (Eds.), A Companion to the Philosophy of Literature (pp. 367-384). New Jersey: John Wiley \& Sons Ltd.

Luangphinith, S. (2015). Hawai'i Literature. In Emannuel S Nelson (Ed.), Ethnic American Literature : An Encyclopedia for Students (pp. 219-227). Connecticut: Greenwood.

Martinez, O. J. (1996). U.S - Mexico Borderlands : Historical and Contemporary Perspectives. New York: Rowman \& Littlefield Publishers, Inc.

Mejia, R., Beckermann, K., \& Sullivan, C. (2018). White lies: A racial history of the (post)truth. Communication and Critical/ Cultural Studies, 15(2), 109-126. https://doi.org/10.1080/14791420.201 8.1456668

Musolff, A. (2019). Factual Narrative and Truth in Political Discourse. In M. Fludernik \& M.-L. Ryan (Eds.), Narrative Factuality (pp. 351-366). W.de Gruyter. https://doi.org/10.1515/978311048627 8-023

Scanlan, E. (2017). Decolonizing the Light: Reading Resistance in Native Hawaiian Poetry. Interventions, 19(7), 976-995. https://doi.org/10.1080/1369801X.201 7.1401950

Schaberg, C. (2018). The Work of Literature in an Age of Post-Truth. London:

Bloomsbury Publishing Plc.

Trask, H.-K. (1999). Decolonizing Hawai'ian Literature. In V. Hereniko \& R. Wilson (Eds.), Inside Out : Literature, Cultural Politics and Identity in the New Pacific (pp. 167-183). New York: Rowman \& Littlefield Publishers, Inc.
Vuorela, U. (2009). Colonial Complicity : the Postcolonial in a Nordic Context. In S. Keskinen, S. Tuori, S. Irni, \& D. Mulinari (Eds.), Complying with Colonialism : Gender, Race and Ethnicity in the Nordic Region (pp. 19-33). Ashgate.

Willsey, K. (2018). "fake vets" and viral lies: Personal narrative in a post-truth era. Journal of American Folklore, 131(522), 500-508. https://doi.org/10.5406/jamerfolk.131.5 22.0500

Worthington, M. (2017). Fiction in the "PostTruth" Era: The Ironic Effects of Autofiction. Critique - Studies in Contemporary Fiction, 58(5), 471-483. https://doi.org/10.1080/00111619.201 7.1331999 